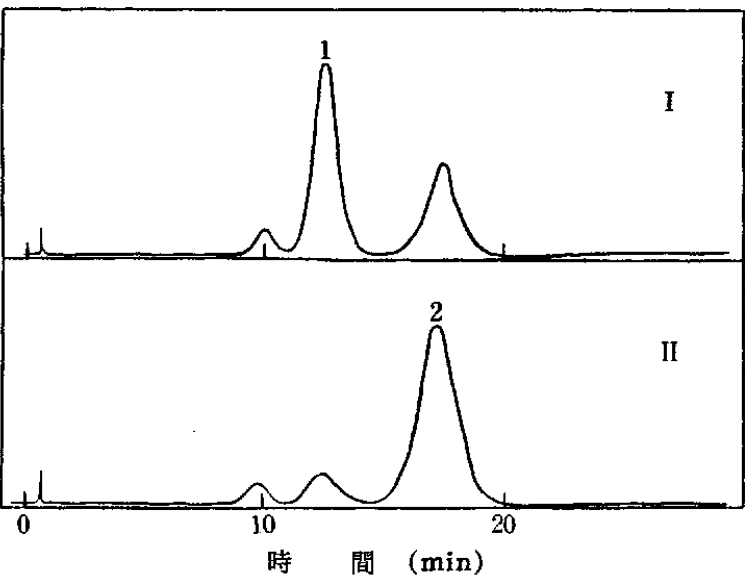

$1:$ 1 イプレゴン, $2:$ プレゴン

I：イソプレゴンを200日間常温放置

I：1 を常圧で 2 時間加熱遠流したもの

図 7 合成インプレゴンの放置および如熱による異性化状況

結晶を得，d-メントンのそれに一致する。また 2,4-ジニトロフ ェニルヒドラゾンをつくれば同様 $\mathrm{mp} 146^{\circ} \mathrm{C}$ の $d$-メントンの 橙色針状結晶を得る。

\section{6 自然放軍および常圧加䍄によるイソプレゴンのプレゴン} への異性化試鈤

シトロネラールから合成したイソプレゴン粗油を常温放置する としだいにプレゴンに異性化するが，さらにこのるの常圧で加 熱襄流すること 2 時問で大部分のイソプレゴンはプレゴンとな る。图 7 および表 6 のようである。

測定条件はシリコン DC $5501.5 \mathrm{~m}$, カラム温度 $165^{\circ} \mathrm{C}$, 流量 ヘリウム $80 \mathrm{ml} / \mathrm{min}$ である。

表 6 イソナ゙レコンの常温放置抢よば加熱による異性化状況

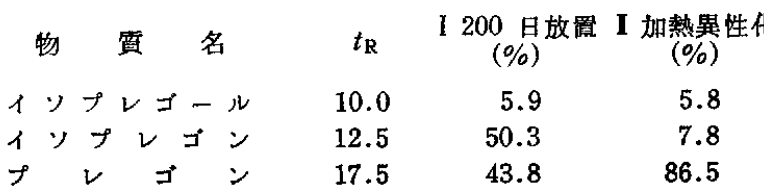

終りに種子の採集送付を扰願いした東京大学费学部北海道演習 林飯塚德義氏, オスロ一系の種子を恵与された武田薬品工業株式 会社京都農園，さらに比較試料をいただいた高砂香料株式会社， および小川香料株式会社住対し梁く感謝する。

(1963 年 10 月, 日本化学会第 7 回香料, テルペン扰よび精油 化学化関する討論会講演)

\title{
D-グルコースとシクロヘキシルアミンとから生成する結昆性付加物の分解*1
}

(明和】39 年 8 月 22 日受理)

石川敏雄

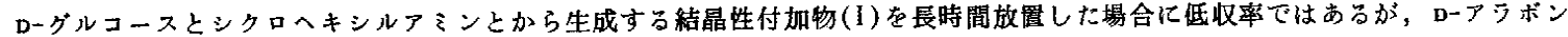

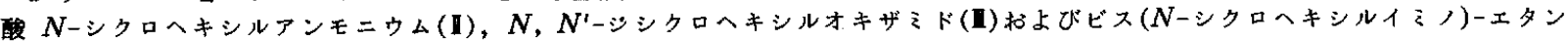
が得られた。I在空気酸化するとI拈よび【が得られた。

备種の $N$-シクロヘキシルグリコシルアミンを臭化カリウム錠澈として 2 年間放置したのちの赤外吸取スペクトルは相互に近诊 レて括り，とくに同一炭素数のグリコシルアミンの場合には酷似していた。

\section{1 緒}

グリコシルアミン類は一般に分解しやすく，容易に悪臭を放つ 暗褐色の粘い物質となる。これは Maillard 反応りとして知られ ているがその際の分解生成物については十分解明されていない。 この分解は空気や水分の存在によって促進されるが, 純䊉に近い 結晶をデシケーター中に置いても長時間を経ると次第に着色して 分解してくる。

藷者はさきに D-グルコースとシクロヘキシルアミンとから生 成する結晶 (I )が $N$-シクロヘキシルーDーグルコシルアミンとシ クロヘキシルアミンとの結晶性付加物であることを確認した2) が, I の分解により二, 三の興味ある生成物を得たので報告す る。

*1との報交を“グリコシルアミンの研究（第 3 報”とする；前報（第 2 報）， 日化 85, 709 (1964).

$\dagger$ 日東理化学研究所，浦和市上木䛴

1) G. P. Ellis, Advances in Carbohydrate Chem. 14, 63 (1959).

2) 石川, 日化 85, 697 (1964).

\section{2 総論}

D-グルコース $1 \mathrm{~mol}$ とシクロヘキシルアミン $2 \mathrm{~mol}$ とから生

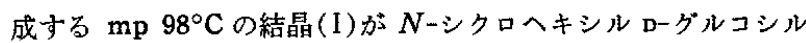
アミンとシクロヘキシルアミンとの結晶性付加物であることはさ きに報告した2)。I は減压下に $70^{\circ} \mathrm{C}$ で乾燥すると次第に着色し ながら隇量して 14 時間後には $25 \%$ 隇量が見られた。この量は I からシクロヘキシルアラン $1 \mathrm{~mol}$ が䑫離した場合の計算減量 $(27 \%)$ 亿近い值である。しかし窒素含量は最初やや減少するがそ の後は増加の傾向を示し最初の窒素含量を越えてくる。この事実 から 25\%の隇量はシクロヘキシルアミンの脱離だけでなく，分 子内脱水および D-グルコース分子の C-C 結合の開裂が起ってい ると考えられる。D-グルコースとシクロヘキシルアミンとから生 成した】をエタノールから再結晶した際の口液を窒温に放置する 々次第に黄褐色に変色し，3〜6箇月するとプリズム状結晶(I)が 少量析出してくる。またときにはごく少量のリン片状結晶( $\mathbf{M}$ )を ともなうことがある。そしてこの場合の着色は黄褐色积度でとど 
まり暗裀色にはなりにくい。これらの結晶の生成の再現 性を思，亦た物成物をさらに多量に得るため二，三の試 験を行なった。采ずこれらの物質の生成要因を長期間放 蜀に上る空父酸化と考え，I沸騰水浴に加熱溶融した。 5 分䦗かきまぜةとIは次第に褐色に変色する。アセ卜

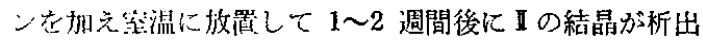
してくる。取辨は $5.3 \%$ であり吕の結晶は生成しなかっ た。

つきには妾エタール溶液とし, 約 $50^{\circ} \mathrm{C} て ゙$ 空気を通 尗と約 5 㭙間で暗褐色となり微量のリン片状結晶が析出 してくる。冷却後口過すると目の結晶であった。口液に アセトンを加光ると沈殿を生じ，これはェタノールで再

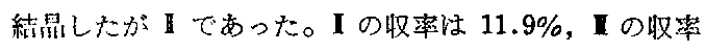
は $1.4 \%$ であった。これと同様の空気酸化の实験を $N-n$-ヘキ シルーローグルコシルアミンについて行なったが，反応終了後 Iに 相当する結晶は析出せず，またアセトンを加えても【に相当する 生成物は得られなかった。

1 性 $\mathrm{mp} 140^{\circ} \mathrm{C}$ で $\mathrm{Nujol}$ 中の赤外吸收スペクトルを見ると 1640 秝よび $1550 \mathrm{~cm}^{-1}$ 付近に強い吸収があり，後者がやや強 い。臭化力リウム錠用法では一定した吸収が得られなかったが， これについては後記する。最初上記の三つの吸收をアミド第 1 , 筑，2吸収と考え，類似物質として $N$-シクロヘキシルーDーグルコ

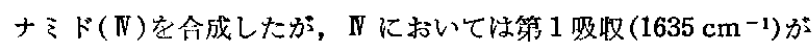
第 2 吸収 $\left(1555 \mathrm{~cm}^{-1}\right)$ よりも強く，またその位置も【とはやや異 なっていた。また臭化カリウム錠剤法でも一定した吸取を与え た。つぎによーアラビノースから製造した $N$-シクロヘキシル $\mathbf{L}$ アラボナミド $(\mathrm{V})$ は $\mathbb{W}$ と類似した赤外吸収を示し，I とは異なっ た物質であった。これら二つのアミドは文献末知の化合物であ る。

I の水溶液にカチオン交換樹脂を加えるとただせに酸性にな り，乐たアニオン交換樹脂を加えるとただちに塭基性になる。こ の事实により【核であると推定された。I の水溶液を Amberlite IR 410(OH 型)カラムに流し, 流出してきたシクロヘキシル アミンを程酸境として $94 \%$ の収率で回取し赤外吸取スペクトル により同定した。つぎに同じカラムに酢酸水溶液を流し, 流出液 を濃縮して加熱乾蜗するとアメ状物が得られる。これにベンジル アミンを反応させて $\mathrm{b}$ アアラボン酸ベンジルアミド(U) (mp $168^{\circ}$ $\left.\sim 170.5^{\circ} \mathrm{C}\right)^{8)}$ 得た。

L-アラビノースを臭素で酸化して L-アラボン酸安つくると， そのシクロヘキシルアミン塩は $\mathrm{mp} 141^{\circ} \mathrm{C}$, 赤外吸収スペクトル (Nujol)も【と一致した。Iは口-䒺列であるので混融すると融点 降下を示した。旋光度はIの量が少なく，比旋光度も小さかった ため命成品と絶対値が一致しなかった。

Iが臭化カリウム錠猎法によって一定した赤外吸収スペクトル を示さなかった原因としては，【と具化カリウムとの閒に壏の複 分解が起って D-アラボン酸カリウムと $N$-シクロヘキシル茄化 アンモニウムを生したためと考光られた。臭化カリウム錠剂製造 の際の孚バチ混和を 15 分以上行なうとほほ完全にこの交換が起

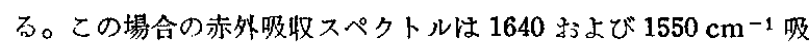
収は非常に弱まり, $1600 \mathrm{~cm}^{-1}$ の吸收がいちじるしく強くなって いる。をた 2030 および $2600 \mathrm{~cm}^{-1}$ 前後の $N$-シクロヘキシル

3) Beilstein, 12, II 569, 九-アラボン酸ベンシルア ミド mp $167^{\circ} \mathrm{C}$.

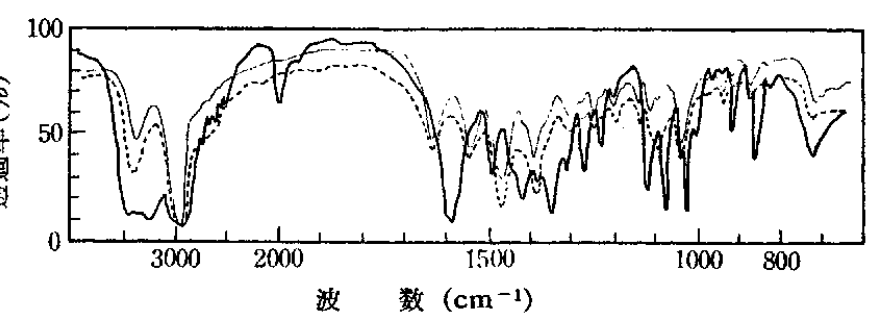

一: D-アラボン酸 N-シクロヘキシルアンモニウム （叜化力りウム錠剂，15 分以上混和）

D-アラボン酸 $N$-シクロヘキシルアンモニウム (Nujol)

——: Lーアラボン酸 $N$-シクロヘキシルアンモニウム

図 1 赤外吸取スペクトル

アンモニウムによる忣収が強く現われた。同様の現象は Dーグル コン酸のシクロヘキシルアミン提においても認められた。

【はやや裀色を率び，水をたは $n$ ーブタノールによる再結晶で

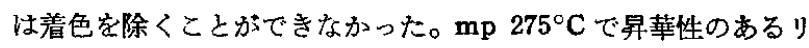
ン片状結晶である。メタノール，エタノール，アセトンなどには 難溶, 水および熱ブタノールにはわずかに溶解した。赤外吸取ス

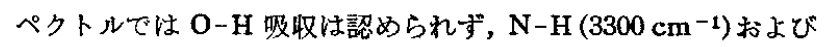

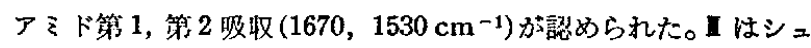
ウ酸ジチルとシクロヘキシルアミンとから合成けした $N, N^{\prime}-$ ジシクロヘキシルオキザミドと融点, 胁外吸取とも一致した。

以上:の放置笵験と同様の实験で，A，Bいずれとも異なる結晶 (VI)がごく微量得られた場合があった。 在もたず，元素分析から酸素を合まないことがわかった。これに より $\mathrm{C}_{6} \mathrm{H}_{11} \mathrm{~N}=\mathrm{CH}-\mathrm{CH}=\mathrm{N}-\mathrm{C}_{6} \mathrm{H}_{11}$ の構造式它推定し，グリオキザ

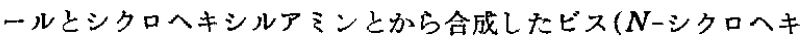
シルイミノ)ーエタンらと宵全に一致することを㒛めた。田は空気 酸化の实駼においては得ることができなかった。

I の酸化により【, 【あるいは、のような結晶が生成し，Nnーヘキシル Dーダルコシルアミンの酸化ではこのような結晶がま ったく得られないことは興昧あるとこつである。この原因が単に シクロヘキシルアミン誘導体が結晶しやすいためか，あるいは I がアミンとの絬晶性付加物であるからとの分解機棈が異なるため であるかは現社のところ不明である。

I と他の N-シクロヘキシルアルドシルアミン類と学それぞれ

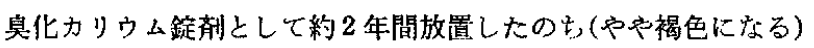
ふたたび赤外眀取スペクトルを測定すると，I，N-シクロへキシ ル ローガラクトシルアミンおよび $N$-シクロヘキシル D-マンノシ

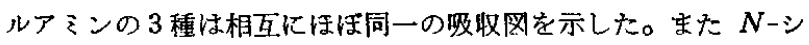
クロヘキシル Lーアラビノシルアミンと $N$-シクロヘキシルロ゙キ

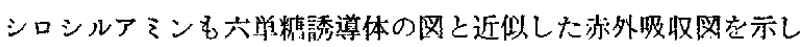
た。マルトース, ラクトース, セロビオースのシクロヘキシルア

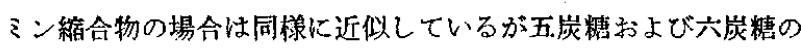
誘首体の場合のように一致した财收図を示さなかった。これら の吸收図を放置前の図と比較すると放固後のるのは 1500～1600 $\mathrm{cm}^{-1}$ の吸收がいちじるしく堌大している。この吸收はアミドあ るいは二車結合などの生成によるものと考えられる。また 880

4) L. M. Rice, C. H. Grogan, E. E. Reid, J. Am. Chem. Soc. 75, 242 (1953)，の方法による。

5) L. Horner, E. Jürgens, Ber. 99, 2184 (1957). 


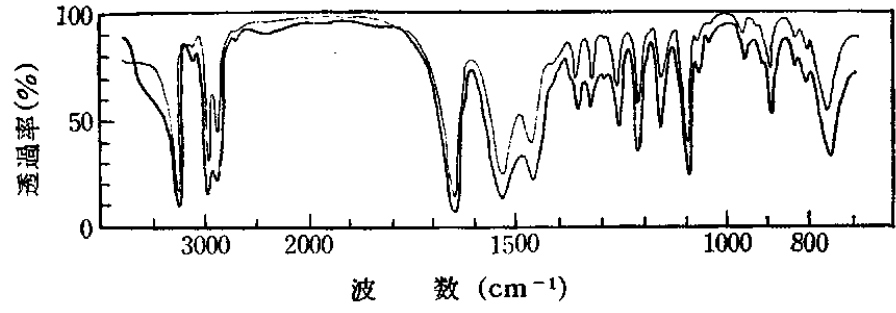

一：１の分解による

- - : シュウ酸エチルとシクロヘキシルアミンの反応による

図 $2 N, N^{\prime}$-シシクロヘキシルオキザるド(I)の赤外吸収スペタトル

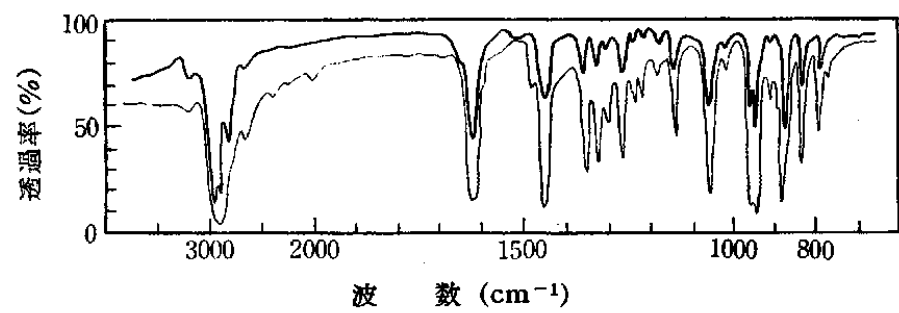

一: I の分解による

一: グリオキザルとシクロヘキシルアミンの反応による

図 3 ピス $(N$-シクロヘキシルイミノ)エタンの赤外吸収スペクトル

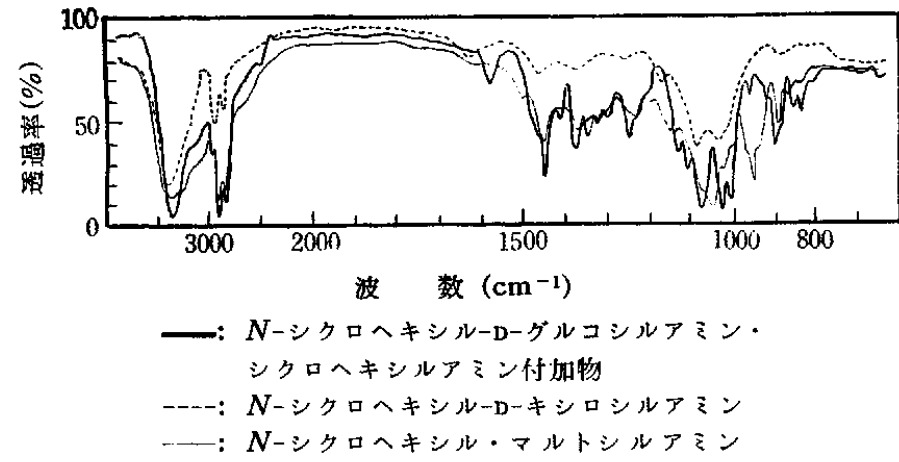

図 4 各種グリコシルアミン類の赤外卯収スペクトル

(臭化カりウム錠剤，放置前）

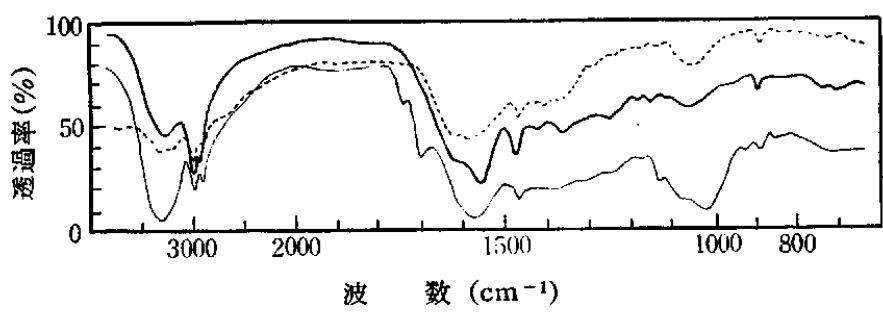

一：NーシクロへキシルーD-グルコシルアミン・ シクロヘキシルアミン付加物

-ーー：N-シクロヘキシルーDーキシロシルアミン

一一: $N$-シクロヘキシル・マルトシルアミン

図 5 各種グリコシルアミン類の赤外吸収スペクトル

(臭化力りウム錠都， 2 年間放置後）

$\mathrm{cm}^{-1}$ に小さく鋭い吸収が見られる。これはフ.ラン環の特性吸収 に類似している゙の゙か明確ではない。これらの $N$-シクロヘキシル

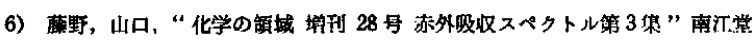
p. 108.
グリコシルアミン類の分解ではいわゆる Maillard 反泣が 起っていると考无られるが，分子内脱水によりフラン誘導 体が生成しているとすれ恬，これらの物翼の放置により類 似した赤外吸収図を示すことは肯定できる。

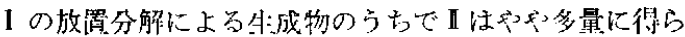

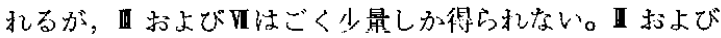

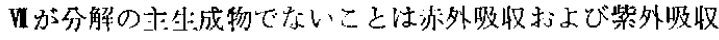

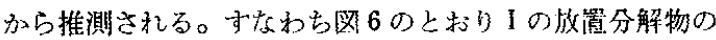
紫外吸収は $310 \mathrm{~m} \mu$ K $\lambda_{\max }$ があるが收の吸は $270 \mathrm{~m} \mu$ に $\lambda_{\max }$ がある。

Dーグルコースをアルカり性:で処理することにより $\mathrm{D}-ア$ ラボン酸堨が生成することが知られているすしかしグル コシルアミンから直接アラボン酸(またはその㙁)を生じる ことは知られていない。I から】を生じる過程についても 一度】が加水分解してからアミン塭基中で酸化分解したと 考えることができる。しかし本実験における分解条件はと くに加水した場合は少ないので，途中に加水分解を経ず 1 から直接目を生じたと考えるのが妥当であるう。

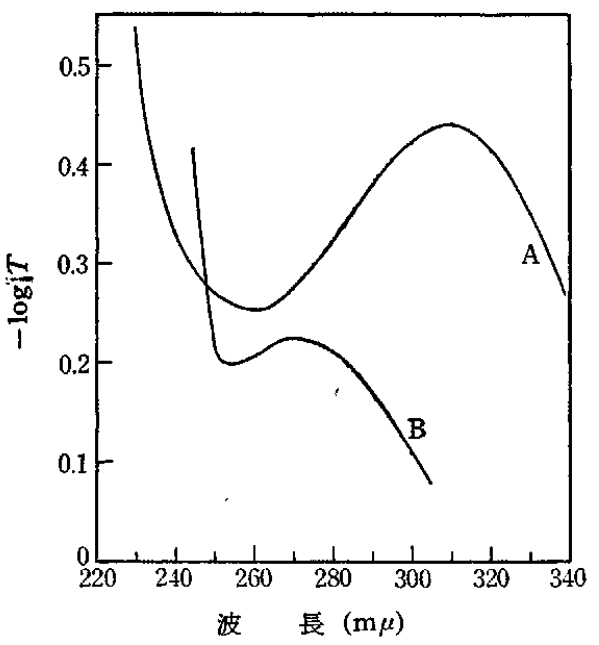

A：I の放置分解物 $(100 \mathrm{mg} / 100 \mathrm{ml})$

B：ビス $(N-$ シクロヘキシルイミノ)エタン $(16.34 \mathrm{mg} / 100 \mathrm{~m} l)$

図 6 紫外吸収スペクトル(エ夕ノ一ル溶液 $)$

Iおよび证の生成についてはグリコシルアミンの分解に より，Iや四のような対称なアミドあるいはイミンが生成 した例は知られていないので今後検討する必要がある。

\section{3 実験*2}

\subsection{II および III の生成}

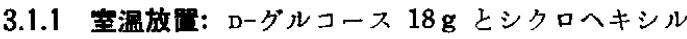
アミン $25 \mathrm{~g}$ を混合して放置したのち，エタノールで再結 晶して I $28 \mathrm{~g}$ 葆得る。液を三角フラスコに入れコルクセ ンをして約 6 箇月放置すると溶媒の大部分屾蒸発して黄褐 色アメ状物となり，その中に少量の結晶が析出してくる。 口别してェタノールで洗って10.18 g 定得た(収率 $3.2 \%$ )。口液

7) O. Spengler, A. Pfannensteil, Z. Wirtschaftsgruppe Zuckerind. Tech. T1. 85, 546 (1935).

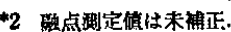


にエタノールを添加すると結晶が析出した。I $1.0 \mathrm{~g}$ (收率 14.1 \%)索得た。

】は水で再總晶しても着色を除けず,昇華によって脱色できた。 $\mathrm{mp} 274^{\circ} \sim 275^{\circ} \mathrm{C}_{0}$

分析值 C $66.94 \%, H \quad 9.69 \%, N 11.05 \%$

$\mathrm{C}_{14} \mathrm{H}_{24} \mathrm{O}_{2} \mathrm{~N}_{2}$ としての

計算值 C $66.63 \% ， \mathrm{H} 9.59 \% ， \mathrm{~N} 11.10 \%$ Iはエタノールで再結晶する。 $\mathrm{mp} 140.5^{\circ} \sim 142^{\circ} \mathrm{C}_{\circ}[\alpha]_{\mathrm{D}}^{20}$ $-4.7^{\circ}(c=5$, 水)。

分析值 C $50.14 \%, \mathrm{H} 9.09 \%, \mathrm{~N} 5.47 \%$

$\mathrm{C}_{11} \mathrm{H}_{23} \mathrm{O}_{e} \mathrm{~N}$ としての

計算値 C $49.80 \%, \mathrm{H} 8.74 \%$, N $5.28 \%$

3.1 .2 I の溶致による II の生成：I $10 \mathrm{~g}$ を沸騰水浴上で溶融 し 5 分間かきまぜると黄色からオレンシ色になり, 冷却後アメ状 物となる。アセトン $40 \mathrm{~m} l$ を加光析出した結晶 (I) $1.1 \mathrm{~g}$ を回収 し口液を空温に放置する。約 1 筒月後 I $0.42 \mathrm{~g}$ (収率, 回収分を 除いて $5.33 \%$ ), mp $130^{\circ} \sim 135^{\circ} \mathrm{C}_{0}$ エタノールで 2 回再結晶し $\tau \operatorname{mp} 140^{\circ} \sim 142^{\circ} \mathrm{C}$ 。

3.1.3 I の空求酸化: $\mathrm{D}-$ グルコース $5 \mathrm{~g}$ とシクロヘキシルアミ ン $6.9 \mathrm{~g}$ を混合し, 固化後エタノール $20 \mathrm{~m} l$ に溶解し冷却器を つけたフラスコ中で $50^{\circ} \mathrm{C}$ に加熱し，液中に空気を吹き込をと液 法黄色から暗褐色になる。15 時間後に結晶が析出してくる。冷 却後口過してて $0.1 \mathrm{~g}$ (收率 1.4\%) 空得る。口液にアセトンを添 加し放置して】1.05 g (収率 $11.9 \%$ ) 它得る。

\section{$3.2 N-n$-ヘキシル D-グルコシルアミンの空気酸化}

D-グルコース $5 \mathrm{~g}$ と $n$-ヘキシルアミン $7.0 \mathrm{~g}$ を 3.1 .3 と同様 に処理して空気酸化する。20 時間後アセトンを加えて 放置する とゲル状沈殿を生じ，他に結晶は析出しない。ゲル状沈殿は $N$ n-ヘキシル D-グルコシルアミンであった。

\subsection{II のイオン交換好理}

I $1.0 \mathrm{~g}$ 水 $30 \mathrm{~m} l$ に溶解し OH 型 Amberlite IR 410 樹脂 カラム $(1.5 \mathrm{~cm}$ 烽 $\times 20 \mathrm{~cm}$ 長 $)$ に流し, $150 \mathrm{ml}$ の水で洗う。通過 液および洗液を $0.1 \mathrm{~N}$ 程酸で中和寸ると $35.6 \mathrm{ml}$ を要した*8。 中和液を滅圧满縮し無色の結晶 $0.48 \mathrm{~g}$ を得た。N-シクロヘキシ ル壏化アンモニウムとして回収率 $94 \%$ であり，赤外吸収は純品 と一致した。

つぎに樹脂カラムに $10 \%$ 酢酸 $30 \mathrm{~m} l$ を流し, 水 $50 \mathrm{~m} l$ で洗 い，通過液および洗液を合わせて濃縮して水アメ状物質を得る。 これを湯浴上に減左下に加熱したのち, ベンジルアえン $1.0 \mathrm{~g}$ 加えて混合する。湯浴上で加熱したのちエタノールを加えると無 色の沈殿を生じる。口過, エタノール再結晶ののち V $0.4 \mathrm{~g}$ を得 る。 $\mathrm{mp} 168^{\circ} \sim 170.5^{\circ} \mathrm{C}$ 。

\subsection{L-アラボン酸シクロヘキシルアンモニウムの合成}

上-アラビノース $1.0 \mathrm{~g}$ 客水 $4 \mathrm{ml}$ に溶かし，臭素 $2.0 \mathrm{~g}$ を加え てよくふり臭素が全部溶解したの名 1 夜放置する。溶液表面に空

\footnotetext{
*3 II $\mathrm{C}_{11} \mathrm{H}_{2} 3 \mathrm{O}_{6} \mathrm{~N}$, 分子量 265 とすると中和必要量は $37.7 \mathrm{~m} l$.
}

気を吹きつけて未反応の真素を除き, OH 型 Amberlite IR 410 アニオン交換カラムに流す。水洗したのち $5 \%$ 酢酸 $100 \mathrm{ml}$ を流 し水で洗う。流出液および洗液を合わせて源縮するとアメ状物 $10.4 \mathrm{~g}(98 \%)$ が得られる。このアメ状物 $0.21 \mathrm{~g}$ にシクロヘキシ ルアミン $0.2 \mathrm{~g}$ を加えるとただもに結晶化し $0.3 \mathrm{~g}(96 \%)$ が得ら れる。エタノールから再結晶して $\mathrm{mp} 140^{\circ} \sim 141^{\circ} \mathrm{C}$, I と混融す ると融点降下宗し $127^{\circ} \sim 135^{\circ} \mathrm{C}_{0}[\alpha]^{25}+3.1^{\circ}(c=5$, 水)。

$\mathrm{C}_{11} \mathrm{H}_{28} \mathrm{O}_{6} \mathrm{~N}$ としての

分析值 C $49.82 \%$, H $8.65 \%, N 5.69 \%$

計算值 C $49.80 \%, \mathrm{H} 8.74 \%, \mathrm{~N} 5.28 \%$

\subsection{III の合成}

市販シュウ酸エチル $2.0 \mathrm{~g}$ にシクロヘキシルアミン $3.0 \mathrm{~g}$ を加

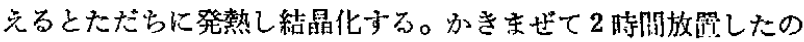
ち口過, 水洗, 乾燥する。 $\mathrm{mp} 275^{\circ} \sim 276^{\circ} \mathrm{C}$ 。I の分解で得た結 晶と混融して $\mathrm{mp} 274^{\circ} \sim 275^{\circ} \mathrm{C}$ 。

\subsection{IV の合成}

南販 D-グルコン酸 $5.0 \mathrm{~g}$ をアスピレーター減圧下に $135^{\circ} \sim$ $140^{\circ} \mathrm{C}$ 油浴で加熱すると発泡, 脱水して溶融する。 3 時間後薄才 レンジ色のアメ状物となる。これにシクロヘキシルアぇン $5.01 \mathrm{~g}$ を加え，加熱しながらよくかきまぜエタノールを加えるとただち に結晶が析出する。 $4.4 \mathrm{~g}$ 。エタノールから再結晶するとリン片 状結晶となる。 $\mathrm{mp} 175^{\circ} \sim 176^{\circ} \mathrm{C}$ 。

分析值 $\mathrm{C} 52.12 \%, \mathrm{H} 8.17 \%, \mathrm{~N} 5.07 \%$

$\mathrm{C}_{12} \mathrm{H}_{23} \mathrm{O}_{5} \mathrm{~N}$ としての

計算值 C $51.97 \%$, H $8.36 \%$, N $5.05 \%$

\section{7 宔温放䝮による VII の生成}

I のエタノール溶液を空温に約 4 筍月放置すると，エタノール は大部分蒸発し淡褐色の水アメ状物となる。これを水中に注ぐと 微量の結晶 ( U) が析出する。 $\mathrm{mp} 149^{\circ} \sim 150^{\circ} \mathrm{C}$ 。

分析值 C $76.26 \%, \mathrm{H} 10.68 \%, \mathrm{~N} 12.40 \%$

$\mathrm{C}_{14} \mathrm{H}_{24} \mathrm{~N}_{2}$ としての

計算储 C $76.31 \%, \mathrm{H} 10.98 \%, \mathrm{~N} 12.71 \%$

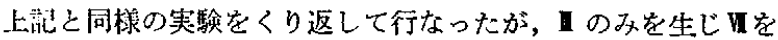
得ることはできなかった。

\subsection{VII の合成}

市販グリオキザル $40 \%$ 水溶液 $5.0 \mathrm{~g}$ とシクロヘキシルアミン $5.0 \mathrm{~g}$ を混合すると，ただちに発熱し固化する。約 2 時間放置し たのた，エタノール $5 \mathrm{ml}$ を加えてロ過する。結晶(V) $2.3 \mathrm{~g}$ 得る。口液に水安加光てさらに $0.7 \mathrm{~g}$ を得る。エ夕ノールから 再結晶をくり返して mp $149^{\circ} \sim 151^{\circ} \mathrm{C}$ 。

3.7 において得た Wと混融して mp $149^{\circ} \sim 150^{\circ} \mathrm{C}$ 。

終始御烈篤な御指运を睗わりました敬藤瀬新一郎先生に厚く御 礼曺し上げます。また御高配を睗わった藤山勝彦理事長ならびに

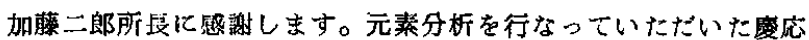
大学工学部梅沢研究室分析室, 括よび東北大学理学部 前藤瀬研究 室分析室の方々に感謝いたします。 